\title{
Alcohol Dehydrogenase 4
}

National Cancer Institute

\section{Source}

National Cancer Institute. Alcohol Dehydrogenase 4. NCI Thesaurus. Code C111833.

Alcohol dehydrogenase 4 (380 aa, $\sim 40 \mathrm{kDa}$ ) is encoded by the human ADH4 gene. This protein plays a role in alcohol oxidation. 